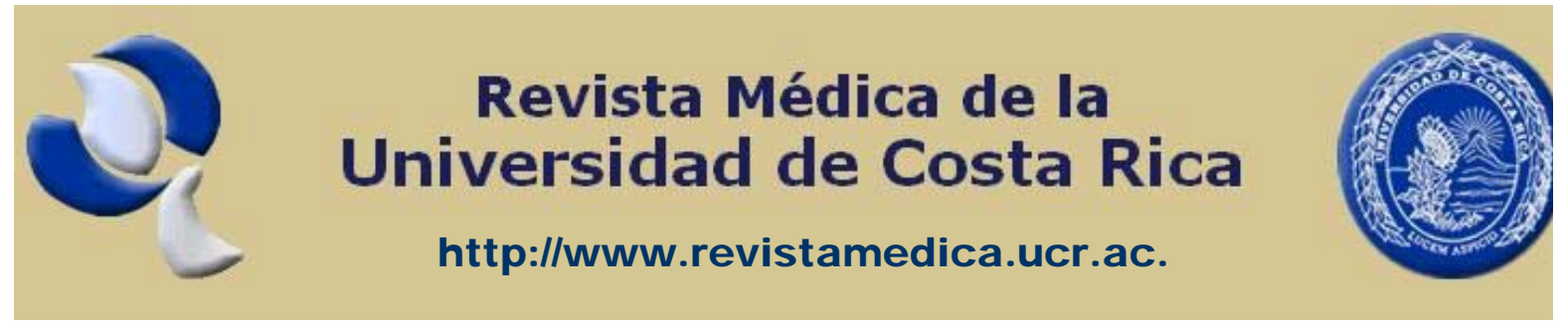

Investigación original

\title{
Antipyretic effect of the aqueous extract obtained from leaves of Neurolaena lobata (Asteraceae) on a pyretic model induced by brewer's yeast.
}

\author{
García-González Mildred $^{1,2}$, Escalante Carlos $^{3}$, Díaz Cecilia ${ }^{\text {2, 4, } 5}$ \\ ${ }^{1}$ Departamento de Fisiología. Escuela de Medicina, Universidad de Costa Rica. \\ ${ }^{2}$ Programa de Productos Naturales y Plantas Medicinales (PRONAPLAMED), Escuela de Medicina, Universidad de \\ Costa Rica. \\ ${ }^{3}$ Hospital México, San José Costa Rica. Programa de Maestría en Ciencias Biomédicas, Universidad de Costa Rica. \\ ${ }^{4}$ Departamento de Bioquímica, Escuela de Medicina, Universidad de Costa Rica \\ ${ }^{5}$ Instituto Clodomiro Picado, Facultad de Microbiología, Universidad de Costa Rica
}

\begin{abstract}
Resumen
Neurolaena lobata es un arbusto propio de las zonas tropicales, que se puede encontrar principalmente en el Caribe y en América Central. De acuerdo con diversas encuestas de TRAMIL, $N$. lobata se utiliza para la preparación de muchos remedios caseros en diversas culturas indígenas de la zona, para tratar enfermedades que presentan fiebre. Basado en esto, el objetivo principal de este trabajo fue la determinación de la posible actividad anti-pirética de los extractos acuosos de las hojas de $N$. lobata. Se utilizaron ratas Wistar $(n=40)$, las cuales fueron divididas en 4 grupos de 10 animales cada uno. En tres de los grupos se indujo fiebre por medio de la administración de levadura de cerveza (como agente pirético). La idea del estudio fue comparar el efecto antipirético del extracto acuoso de las hojas de $N$. lobata con el del acetaminofén, así como también comparar ambos efectos con el producido por el control de agua destilada (placebo). Los tres grupos que recibieron levadura de cerveza experimentaron el efecto pirético esperado $(p<0.05)$, mientras que el grupo al que no se le suministró la levadura,
\end{abstract}

Revista electrónica publicada por la Escuela de Medicina de la Universidad de Costa Rica, 20 2060 San José, Costa Rica. ® All rights reserved. 
no mostró ningún efecto. El grupo A recibió agua destilada como placebo (2 ml/animal), el grupo B recibió acetaminofén como tratamiento antipirético (grupo control positivo; $1000 \mathrm{mg} / \mathrm{kg}$ ), el grupo C recibió el extracto acuoso de las hojas de $\mathrm{N}$. lobata (solución experimental; $2000 \mathrm{mg} / \mathrm{kg}$ ) y el grupo D no recibió ningún tratamiento (control negativo). El grupo A no mostró ningún efecto antipirético, mientras que los grupos $B$ y $C$ mostraron un efecto antipirético estadísticamente significativo $(p<0.05)$ y en ambos grupos el efecto se observó a los 30 minutos después de la administración. En conclusión, en este estudio se mostró que las hojas de $N$. lobata en solución acuosa tienen actividad antipirética, por lo que el uso tradicional es validado en ratas. Este extracto puede ser de utilidad parcial como remedio para controlar la fiebre en ausencia de otros medicamentos disponibles.

Palabras claves: Neurolaena lobata, antipirético, fiebre, levadura de cerveza, gavilana

\begin{abstract}
Neurolaena lobata is a bush native of the tropics, that can be found mainly in the Caribbean and Central American areas. Based on TRAMIL surveys, N. lobata leaves are used for the preparation of many remedies among the indigenous cultures, to treat several illnesses associated with fever. Based on that, the main objective of this study was to determine whether the aqueous extract of $N$. lobata leaves has antipyretic activity on an experimental animal system. We used Wistar rats $(n=40)$, which were divided into 4 groups, and fever was induced in 3 of the groups with brewer's yeast. The idea behind the study was to compare the antipyretic effect obtained with acetaminophen and the aqueous extract of $N$. lobata leaves, and both of them with a control of distilled water (placebo). All three groups receiving brewer's yeast experienced a pyretic statistically significant effect $(p<0.05)$, while the negative control that did not receive the yeast challenge, showed no effect. Group A received distilled water as a placebo (2 $\mathrm{ml} /$ animal), group B received acetaminophen as an antipyretic treatment $(1000 \mathrm{mg} / \mathrm{kg})$, group $C$ received the aqueous extract of $N$. lobata leaves as the experimental solution (2000 mg/kg) and Group D received no treatment (negative control). Group A shown no antipyretic effect, while groups B and C showed an effect of up to $2.9{ }^{\circ} \mathrm{C}(p<0.05)$. Treatment with acetaminophen and $N$. lobata extract showed an antipyretic effect within 30 minutes. In conclusion, we showed that the aqueous extract of $N$. lobata leaves has an antipyretic effect, therefore the traditional use is validated in rats. This extract could be partially helpful as a remedy to control fever in the absence of other available drugs.
\end{abstract}

Key words: Neurolaena lobata, antipyretic, fever, brewer's yeast, gavilana

Revista electrónica publicada por la Escuela de Medicina de la Universidad de Costa Rica, 


\section{Introduction}

Neurolaena lobata is a bush which can grow up to four meters high, with elongated leaves ranging from 5 to $24 \mathrm{~cm}$ long. N. lobata is a native to the tropics and can be found mainly in the Caribbean and Central America. Depending on the country, it is called by several different names: "gavilana" in Costa Rica, "jackass bitter" in Antigua and Barbados, "salvia" in Cuba, and "mano de lagarto" in Honduras. Based on information collected through TRAMIL surveys, $N$. lobata has been used to treat several diseases including diabetes, stomach aches, and the common cold, among others, and some illnesses that present fever $[1,2]$.

Extracts from the leaves and stems of $N$. lobata have been shown to contain different germacranolides, including neurolenin B [3]. Also up to twelve different flavonoides and some by-products of thymol have been isolated from this plant [4]. Regarding to its toxicity, doses ranging from 1 to 5 $\mathrm{g} / \mathrm{kg}$ of, both leaves and the whole plant aqueous extract, have been administered to mice without showing obvious adverse effects [2].

In the last few years, several different scientific studies have validated some of the popular uses of $N$. lobata. Recently, it was shown that an ethanol extract of $N$. lobata leaves had an important filaricidal effect when given at concentrations ranging from 125 to 1000

\section{Material}

Plants: N. lobata was collected in August, 2005 in Fortuna, San Carlos, Alajuela province (Costa Rica) by biologist and taxonomist Alonso Quesada (1501). A sample of this $\mathrm{mg} / \mathrm{ml}$. This extract has been applied in vitro and in vivo against Brugi pahangi, and its effect has been shown to be dose dependent [5].

Studies have also shown that $N$. lobata has an antiprotozooal effect. An study showed that an ethanol extract of $N$. lobata leaves was capable of inhibiting the growth of Leishmania mexicana, Trypanozoma cruzi and Tricomonas vaginalis through the effects of its germacranolides 1, 2 and 3 [6].

Other studies have proven that $N$. lobata has a neutralizing effect on the hemorrhaging properties of the Bothrops atrox venom on mice. An alcoholic extract was used for this purpose and a local intradermic application was proven to be more efficient than an oral or intravenous application [7].

Studies done in rats, using a hydroalcoholic extract of $N$. lobata leaves, have shown that $N$. lobata has a protective effect on the gastric mucosa, reducing the incidence of gastric ulcers by up to $57 \%$ during stress tests [8]. The same authors had previously shown that a $N$. lobata hydroalcoholic extract of the leaves had analgesic and antiinflammatory effects on rats [9].

Based on the fact that most of the diseases for which $N$. lobata is used, present fever, we decided to investigate whether the aqueous extract of the leaves of this plant has effective antipyretic activity.

material was placed in the National Herbarium of the National Museum of Costa Rica, with the reference number CR-0241340. 
Aqueous extract: $4 \mathrm{~kg}$ of fresh leaves were homogenized in 7.5 liters of distilled water and heated to $80^{\circ} \mathrm{C}$ for 30 min. The extract was filtered through a gauze and lyophilized, yielding $120 \mathrm{~g}$ of material. With this sample, an aqueous solution of $200 \mathrm{mg} / \mathrm{ml}$ was prepared.

\section{Methods}

The following solutions were used: $20 \%$ brewer's yeast aqueous solution [10], aqueous extract of of $N$. lobata leaves (200 $\mathrm{mg} / \mathrm{ml})$, and $100 \mathrm{mg} / \mathrm{ml}$ acetaminophen (Calox International) [11].

Animals were divided into four groups by randomization and the groups were labeled A, B, C or D. Basal rectal temperatures were measured using OMRON digital thermometers (model MC-120). Before the experiment, animals were left overnight with water ad libitum. The next day basal temperatures were measured and animals from groups $A, B$ and $C$ received $a$ subcutaneous injection of brewer's yeast solution at a dose of $4 \mathrm{~g} / \mathrm{kg}$ of body weight. Rectal temperatures were

\section{Results}

Basal temperature of groups A (water), $B$ (acetaminophen), C (plant extract) and $\mathrm{D}$ (no treatment), were $36.88 \pm 0.35{ }^{\circ} \mathrm{C}$, $36.79 \pm 0.54{ }^{\circ} \mathrm{C}, \quad 36.81 \pm 0.46{ }^{\circ} \mathrm{C}$ and $36.82 \pm 0.27{ }^{\circ} \mathrm{C}$, respectively. There was no statistically significant differences among the groups. After injecting groups After confirming the pyretic effect induced by brewer's yeast, each group received its corresponding treatment to test the potential antipyretic effect at 30, 60 and 90 minutes. We observed no
Animals: Forty male Wistar rats were obtained from Laboratorio de Ensayos Biológicos, Universidad de Costa Rica. The average weight of the animals was $180.8 \pm 13.3$ g. Standard laboratory procedures were followed for their care.

measured in all groups, 17 and 18 hours after brewer's yeast injection according to previous validation assays done with Wistar rats, to assure pyretic activity (data not shown). After the $18^{\text {th }}$ hour of temperature measurement, the following solutions were given orally: Group A: Distilled water, $2 \mathrm{ml} /$ animal (placebo); Group B: acetaminophen, $1000 \mathrm{mg} / \mathrm{kg}$ (antipyretic positive control); Group C: $N$. lobata leaves extract, $2000 \mathrm{mg} / \mathrm{kg}$ (experimental solution); Group D: no treatment (negative control).

Rectal temperatures were then measured 30, 60 and 90 minutes after the treatment was applied, to determine antipyretic activity. Data was collected and analyzed (ANOVA, $p<0.05$ ).

A, B and C with brewer's yeast, it was observed a sustained pyretic effect at 17 and 18 hours post-injection, representing a statistically significant difference compared to their basal temperatures $(p<0.05)$, but no significant difference among the groups (Table 1). effect with water, but both acetaminophen and $N$. lobata had a clear antipyretic effect. There were no changes in the untreated group (Table 2).

Revista electrónica publicada por la Escuela de Medicina de la Universidad de Costa Rica, 
At the time-response graph, it can be observed the pyretic effect of brewer's yeast and the antipyretic activities induced by acetaminophen and $N$. lobata aqueous extract (Figure 1).

Table \# 1. Basal temperatures and pyretic effect induced by brewer's yeast on Wistar rats

\begin{tabular}{|lcc|c|}
\hline & Basal & 17 hr post B.Y. & 18 hr post B.Y. \\
\hline Distilled water & $36.88 \pm 0.35{ }^{\circ} \mathrm{C}$ & $37.83 \pm 0.28^{\circ} \mathrm{C}^{*}$ & $38.01 \pm 0.19^{\circ} \mathrm{C}^{*}$ \\
\hline Acetaminophen & $36.79 \pm 0.54{ }^{\circ} \mathrm{C}$ & $37.69 \pm 0.28^{\circ} \mathrm{C}^{*}$ & $38.04 \pm 0.25{ }^{\circ} \mathrm{C}^{*}$ \\
\hline N. lobata extract & $36.81 \pm 0.46{ }^{\circ} \mathrm{C}$ & $37.74 \pm 0.16{ }^{\circ} \mathrm{C}^{*}$ & $37.97 \pm 0.39{ }^{\circ} \mathrm{C}$ \\
\hline No treatment & $36.82 \pm 0.27^{\circ} \mathrm{C}$ & $36.63 \pm 0.23^{\circ} \mathrm{C}$ & $36.53 \pm 0.46{ }^{\circ} \mathrm{C}$ \\
\hline
\end{tabular}

B.Y.= Brewer's yeast. ${ }^{1}=$ Group D did not receive brewer's yeast. * = statistically significant increase compared to basal temperature $(p<0.05)$.

Table \#2. Antipyretic effect of N. lobata extract treatment on Wistar rats

\begin{tabular}{|c|c|c|c|c|}
\hline Treatment & $\begin{array}{c}18 \mathrm{hr} \text { post } \\
\text { B.Y. }\end{array}$ & $\begin{array}{c}30 \min _{T x} \text { post } \\
\text {. }\end{array}$ & $\begin{array}{c}60 \min _{T x} \text { post } \\
\text {. }\end{array}$ & $\begin{array}{c}90 \min _{T X} \text { post } \\
\text {. }\end{array}$ \\
\hline Distilled water & $\begin{array}{l}38.01 \pm \\
0.19^{\circ} \mathrm{C}\end{array}$ & $\begin{array}{c}37.87 \pm 0.22 \\
{ }^{\circ} \mathrm{C}\end{array}$ & $\begin{array}{c}38.01 \pm 0.27 \\
{ }^{\circ} \mathrm{C}\end{array}$ & $\begin{array}{c}38.04 \pm 0.18 \\
{ }^{\circ} \mathrm{C}\end{array}$ \\
\hline Acetaminophen & $\begin{array}{l}38.04 \pm \\
0.25^{\circ} \mathrm{C}\end{array}$ & $\begin{array}{c}35.66 \pm 1.17 \\
{ }^{\circ} \mathrm{C}^{*}\end{array}$ & $\begin{array}{c}35.05 \pm 0.99 \\
{ }^{\circ} \mathrm{C}^{*}\end{array}$ & $\begin{array}{c}35.14 \pm 0.83 \\
{ }^{\circ} \mathrm{C}^{*}\end{array}$ \\
\hline N. lobata extract & $\begin{array}{l}37.97 \pm \\
0.39^{\circ} \mathrm{C}\end{array}$ & $\begin{array}{c}37.17 \pm 0.60 \\
{ }^{\circ} \mathrm{C}^{*}\end{array}$ & $\begin{array}{c}36.98 \pm 0.82 \\
{ }^{\circ} \mathrm{C}^{*}\end{array}$ & $\begin{array}{c}37.21 \pm 0.62 \\
{ }^{\circ} \mathrm{C}^{*}\end{array}$ \\
\hline No treatment $t^{1}$ & $\begin{array}{l}36.53 \pm \\
0.46^{\circ} \mathrm{C}\end{array}$ & $\begin{array}{c}36.46 \pm 0.44 \\
{ }^{\circ} \mathrm{C}\end{array}$ & $\begin{array}{c}36.56 \pm 0.30 \\
{ }^{\circ} \mathrm{C}\end{array}$ & $\begin{array}{c}36.47 \pm 0.56 \\
{ }^{\circ} \mathrm{C}\end{array}$ \\
\hline
\end{tabular}

B.Y.= Brewer's yeast. TX. $=$ Treatment. ${ }^{1}=$ Group D did not receive brewer's yeast. ${ }^{*}=$ statistically significant decrease compared to temperatures at $18 \mathrm{hrs}$ post B.Y. administration $(p<0.05)$.

Revista electrónica publicada por la Escuela de Medicina de la Universidad de Costa Rica,

2060 San José, Costa Rica. ${ }^{\circledR}$ All rights reserved. 


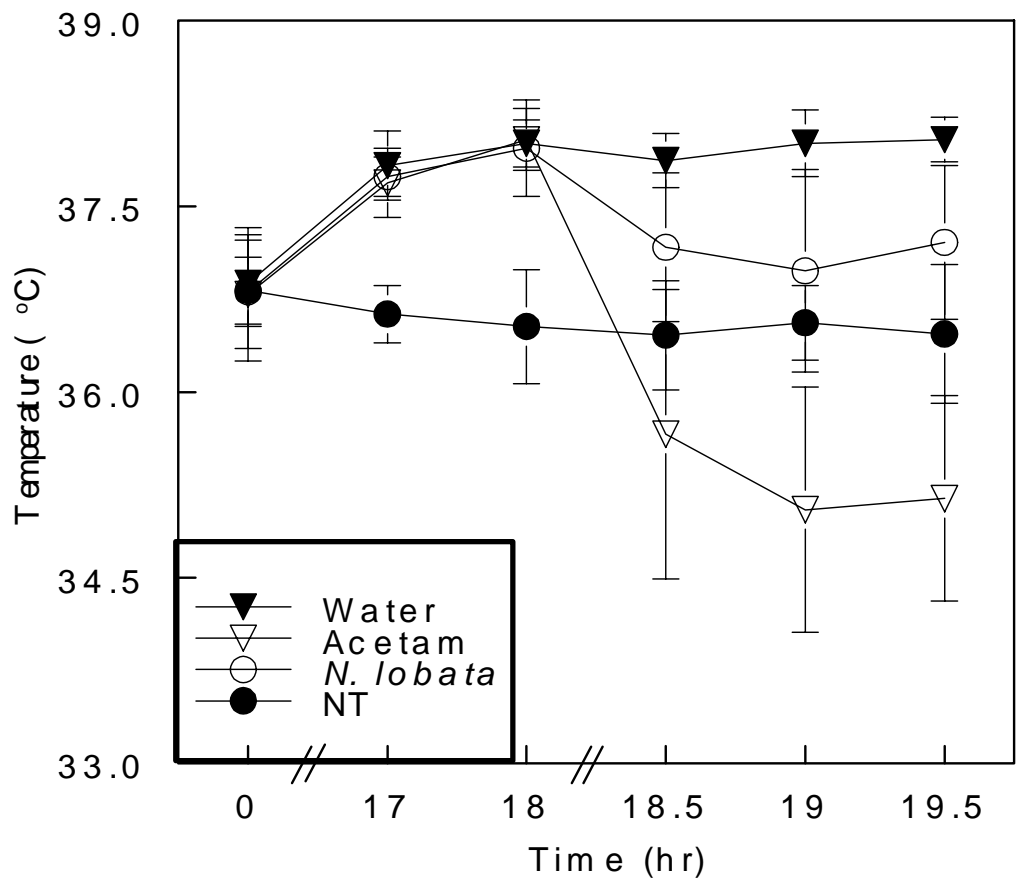

Figure \# 1. Time course of the pyretic effect induced by brewer's yeast and antipyretic activity of different treatments (time is not at exact scale to illustrate the effect more clearly). NT= no treatment.

\section{Discussion}

In this study, pyrexia was induced with brewer's yeast because it is one of the easiest and more reproducible methods reported in the literature [10]. Based on a previous validation test with 20 Wistar rats, we decided to use the $18^{\text {th }}$ hour as the time point to test the antipyretic effect of our extract, because it is the point at which the pyretic effect has stabilized. Also, the $18^{\text {th }}$ hour point is the one reported in several other previous studies [10]. As was expected, groups A, $B$ and $C$, which received brewer's yeast, showed a pyretic effect average of 1.12 ${ }^{\circ} \mathrm{C}$, which was statistically significant $(p<0.05)$. Group D did not receive any treatment, and its average temperature did not vary significantly during the course of the study.

Group A, which received distilled water, was used as a controlled placebo and, as expected, no changes in temperature were observed in this group. Group B, which received acetaminophen, exhibited a maximum decrease in temperature of up to $2.99{ }^{\circ} \mathrm{C}$. This

Revista electrónica publicada por la Escuela de Medicina de la Universidad de Costa Rica, 
antipyretic effect was evident 30 minutes after administration and was statistically significant $(p<0.05)$. The experimental group, group $\mathrm{C}$, received $N$. lobata leaves extract. This group had an antipyretic effect evident also 30 minutes after administration with a maximum antipyretic effect of $0.81^{\circ} \mathrm{C}$.

As it has been described before [12], isoflavones have antipyretic effects. Kerr and collaborators [4] had isolated 12 different flavonoides from $N$. lobata and it is suggested that these could be some of the components responsible for $N$. lobatas' antipyretic effect. In a similar, but more detailed study [13], it was

\section{References}

1. Girón L.M., Freire V., Alonzo A., Cáceres A. Ethnobotanical survey of the medicinal flora used by the Caribs of Guatemala. Journal of Ethnopharmacology. 1991; 34(2/3): 173-187.

2. Hacia una Farmacopea Caribeña. Investigación científica y uso popular de plantas medicinales en el Caribe. Germonsén-Robineau L. (ed). Edición TRAMIL 7. Enda-Caribe. Santo Domingo. 1995. 696 pp.

3. Passreiter C.M., Aldana B.E. Variability of sesquiterpene lactones in Neurolaena lobata of different origin. Planta Medica. 1998. 64(5): 427430.

4. Kerr K., Mabry T. \& Joser S. 6-hydroxy and 6 methoxyflavonoids from Neurolaena lobata and N. macrocephala. Phytochemistry. 1981; 20(4): 791-794.

5. Fujimaki Y., Kamachi T., Yangi T., Caceres A., Maki J. \& Auki Y. Macrofilaricidal and microfilaricidal effects of Neurolaena lobata, a Guatemalan medicinal plant, on Brugia pahangi. Journal of Helminthology. 2005; 79(1): 23-28. shown that Pueraria lobatas' isoflavones were responsible for the antipyretic effect induced by this plant, but an antipyretic effect of other germacranolides has not been demonstrated [14].

This study validated the antipyretic effect attributed to $N$. lobata. We suggest that, in situations were there is no immediate access to medical care, or where traditional and indigenous herbal medicine is the mainstream treatment of disease, $N$. lobata may play an effective role in relieving the pyretic symptoms of some diseases.

6. Berger I., Passreiter C.M., Caceres A. \& Kubelka W. Antiprotozoal activity of Neurolaena lobata. Phytotherapy Research. 2001; 15(4): 327-330.

7. Otero R., Nunez V., Barona J., Fonnegra R., Jimenez S.L., Osorio R.G., et al. Snakebites and ethnobotany in the northwest region of Colombia. Part III: neutralization of the haemorrhagic effect of Bothrops atrox venom. Journal of Ethnopharmacology. 2000; 73(1-2): 233-241

8. Gracioso J.S., Hiruma-Lima C.A. \& Souza Brito A.R. Antiulcerogenic effect of a hydroalcoholic extract and its organic fractions of Neurolaena lobata (L.) R.BR. Phytomedicine. 2000; 7(4): 283-289.

9. Gracioso J.S., Paulo M.Q., Hiruma-Lima C.A. \& Souza Brito AR. Antinociceptive effect in mice of a hydroalcoholic extract of Neurolaena lobata (L.) R. Br. and its organic fractions. Journal of Pharmacy and Pharmacology. 1998; 50(12): 1425-1429.

10. Bhat A.S., Tandan S.K., Kumar D., Krishna V., \& Prakash V.R. Interaction between inhibitors of inducible nitric oxide synthase and cyclooxygenase in brewer's yeast induced pyrexia in mice: an isobolographic study.

Revista electrónica publicada por la Escuela de Medicina de la Universidad de Costa Rica, 
European Journal of Pharmacology. 2005; 511(2-3): 137-142.

11. Devi B.P., Boominathan R., Mandal S.C. Evaluation of antipyretic potential of Cleome viscose Linn. (Capparidaceae) extract in rats. Journal of Ethnopharmacology. 2003; 87(1):113.

12. Chueh F.S., Chang C.P., Chio C.C. \& Lin M.T. Puerarin acts through brain serotoninergic mechanism to induce thermal effects. Journal of Pharmacological Sciences. 2004; 96(4): 420427.

[13] Yasuda T., Endo M., Kon-on T., Kato T., Mitsuzuka M., \& Ohsawa K. Antipyretic, analgesic and muscle relaxant activities of pueraria isoflavonoids and their metabolites from Pueraria lobata Ohwi - a traditional Chinese drug. Biological and Pharmaceutical Bulletin. 2005; 28(7): 1224-1228.

14. Matsuura N., Yamada M., Suzuki H., Hasegawa N., Kurosaka C., Ubukata M., et al. Inhibition of preadipocyte differentiation by germacranolides from Calea urticifolia in 3T3L1 cells. Bioscience, Biothechnology and Biochemistry. 2005; 69(12): 2470-2474.

\section{Correspondencia:}

\section{Mildred García González}

Departamento de Fisiología. Escuela de Medicina, Universidad de Costa Rica.

mildredg@cariari.ucr.ac.cr

Revista electrónica publicada por la Escuela de Medicina de la Universidad de Costa Rica, 